\title{
Prospectives for using artificial scaffolds in oral and craniofacial surgery: literature review
}

\author{
Andrey I. Yaremenko ${ }^{1}$, Anna V. Lysenko${ }^{1}$, Elizaveta A. Ivanova ${ }^{1}$, Alexander D. Vilesov ${ }^{1,2}$, Oleg V. Galibin ${ }^{1}$, \\ Nikolay L. Petrov ${ }^{1}$, Pavel A. Kirillov ${ }^{1}$ \\ ${ }^{1}$ Department of Faciomaxillar Surgery, R. M. Gorbacheva Research Institute of Children Oncology, Hematology and Transplantology, \\ Research Center; The First St. Petersburg State I. P. Pavlov Medical University, St. Petersburg, Russia \\ ${ }^{2}$ Institute of Macromolecular Compounds Russian Academy of Sciences, St. Petersburg, Russia
}

Dr. Elizaveta A. Ivanova, Department of Faciomaxillar Surgery, The First St. Petersburg State I. P. Pavlov Medical University, L. Tolstoy St 6-8, 197022, St. Petersburg, Russia
Phone/Fax: +7 (812) 2344542

E-mail: Lizabet159@yandex.ru

\section{Summary}

Regenerative medicine is an emerging field of biotechnology that combines various aspects of medicine including cell and molecular biology, material science and bioengineering - to regenerate, repair or replace tissues. Bone regeneration is a promising approach in dentistry and is considered an ideal clinical strategy in treating diseases, injuries, and defects of the maxillofacial area. Advances in tissue engineering have resulted in the development of innovative scaffold designs, complemented by the progress made in cell-based therapies. In vitro bone regeneration can be achieved by the combination of stem cells, scaffolds, and bioactive factors. A possible improvement in restoring damaged tissues may be achieved by load- ing the scaffolds with drug substances, as well as genetic material, growth factors or other proteins, promoting the tissue regeneration. This review focuses on different biomaterials currently used in dentistry, as potential scaffolds for bone regeneration when treating bone defects, or in surgical interventions, including characteristics and types of these scaffolds, and a literature review of local antibiotic delivery by combined usage of scaffolds and drug-delivery systems.

\section{Keywords}

Craniofacial surgery, scaffold, tissue engineering, stem cells, drug delivery.

\section{Introduction}

Bone tissue engineering aims to restore tissues damaged due to a trauma, diseases, or congenital abnormalities [1]. The regeneration of facial skeletal tissues must consider ways to ensure the recovery of aesthetic characteristics. Additionally, the bone reconstruction should keep sufficient mechanical strength to protect internal organs and support movements enabling normal speech and masticatory functions [2].

Tissue engineering is a multidisciplinary field focused on the development of materials and strategies by merging the principles, methods and knowledge of chemistry, physics, engineering and biology [3]. This approach involves three fundamental elements: cells, scaffolds, and cell signaling, which are vital for eliciting the essential response from a designed tissue-engineered system [4]. The principles of tissue engineering have found widespread application in several branches of dentistry, such as periodontics, oral maxillofacial surgery, and implant dentistry. In implantology the most frequently observed problems are the lack of adequate bone tissue, proximity to important anatomical structures (such as the maxillary sinus and the inferior alveolar nerve) at the implantation site [5]. Multiple approaches to the treatment and restoration of craniofacial bone defects exist where tissue autografting and allografting are considered the best options [6]. However, these strategies are associated with intrinsic drawbacks, including limited availability of autologous grafts, and potential immunogenic rejection when attempting allogeneic grafting. Tissue engineering has been found to be a clinically relevant approach aiming for the promotion of tissue regeneration in craniofacial regions [7].

Tissue regeneration is a process which takes place after an acute injury, and it can be achieved by the restoration or re- 
pair of tissue structure. Formally speaking, the term regeneration refers to the complete reconstitution of lost or damaged tissue, whereas repair means restoration of some original structure followed by scar formation [8]. Relative contribution of regeneration and scarring of the tissue repairs depends on ability of the specialized tissue to regenerate, and on the extent of injury. A promising approach is to induce tissue regeneration at the defective site by introducing a solid scaffold acting as artificial extracellular matrix (ECM) [9]. Its surface promotes cell attachment, their subsequent proliferation and differentiation. Biocompatibility of artificial ECM is of great importance, since the surrounding cells find a favorable microenvironment for their homing and proliferation within such a scaffold. It can be implanted into the body as a cell-free scaffold, or it may be already supplied with cells and/or growth factors, cytokines, and genetic material (bioengineered scaffolds). The latter has the advantage by promoting faster tissue regeneration, especially in some pathological conditions, when the tissue does not have inherent self-regenerating potential [10].

To overcome the drawbacks of particulate bone graft materials, the three-dimensional (3D) porous biodegradable scaffolds have been introduced to dentistry clinics [11]. 3D porous scaffolds can maintain the physical space necessary for bone regeneration, thus not only preventing invasion of undesired cells but also anchoring endogenous osteogenic cells to induce cell in-growth and providing molecular environment for osteoblastic differentiation. The fabrication of an ideal personalized scaffold of precise shape and size has recently become possible with 3D bioprinting systems (3DPs) [12]. Synthetic polymers, such as polycaprolactone (PCL), are commonly used for the scaffold fabrication, because of their thermoplastic characteristics and suitable layer-by-layer processing of scaffolds by means of 3DPs [13]. In addition, PCL is a safe FDA-approved material for use in drug delivery devices and implantation scaffolds. Due to its biocompatibility and biodegradability, the PCL material can be employed as a bone substitute to reconstruct alveolar bones in the oral cavity [14].

Along with growth-promoting proteins, genes, and other stimulatory factors, common antibiotics and anti-inflammatory drugs are of utmost importance for successful tissue regeneration [15]. Antibiotic administration is fundamental to reduce infection risks during the implantation procedure and healing process, or to treat pre-existing infections. Anti-inflammatory drugs reduce inflammation at the site of scaffold implantation, thus promoting the healing of damaged tissue [16].

Extensive literature available on this topic highlights, how the most studied and suitable strategy involves the incorporation of drugs into scaffolds, or their encapsulation into polymeric drug-delivery systems that can be combined with the scaffold. In these terms, biodegradable polymers are potentially interesting and widely studied materials.

After a brief introduction, the following sections are dedicated to clarify the characteristics of scaffolds for bone regeneration and implantation in the maxillofacial region.

\section{Structure of the craniofacial bone tissues}

Orofacial structures are very unique in their development and function. Craniomaxillofacial bones consist of cranial and facial bones. Cranial bones enclose the brain and function mostly to protect it, whereas different facial bones such as the maxillary and mandible act as load-bearing bones for the dental region [17]. Bone consists of collagen fibers which are mineralized by hydroxyapatite (HA) to give a crystal structure and thus to provide mechanical strength. Osteoblasts differentiated from the bone marrow-derived mesenchymal stem cells (BMMSCs) regulate osteoid secretion and bone mineralization. Before osteoid mineralization, 94\% of the osteoid is collagen fiber [18]. When the bone develops, osteoid is mineralized by calcium apatite to form a HA-like structure. Once the mineralization is complete, the calcified bone is composed of $25 \%$ organic matrix, $70 \%$ mineral and $5 \%$ water [18]. Bones are highly vascularized to provide nutrients and oxygen to the bone cells and to remove debris in the extracellular matrix. Other than osteoblasts, osteocytes and osteoclasts also facilitate bone regeneration and remodeling. In general, orofacial tissues have limited and variable capacity for regeneration [19].

\section{Artificial scaffolds for bone tissue regeneration}

A scaffold for tissue regeneration is a structure which is able to support and/or promote tissue regeneration. It should possess a $3 \mathrm{D}$ and well-defined macro-architecture and micro-architecture with an interconnected pore network [20].

Bone tissue presents anisotropic behavior because its strength depends on orientation of the applied load and resistance to high pressure/loadings, and the resistance depends on the positioning of bone in the human body and its size. For these reasons, specific scaffold structure, shape, and composition may be useful, according to the bone restoring needs. All these variables (shape, structure, and composition) should be balanced in order to find the combination that perfectly matches with the properties and functions of the damaged bone. This means a significant number of combinations among polymers, minerals, and other materials need to be evaluated [10].

Critical issues related to allograft and autograft implants are identified as high risk of infections, painful procedures needed to harvest bone graft from the iliac crests, and long post-operative recovery [21]. In addition, autograft and allograft implants are made of avascular and non-viable tissue; they do not carry cellular components of bones, resulting in a lack of bone remodeling. The rates of failure for these procedures are up to $25-35 \%$, due to graft rejection induced by the host immune system [22].

Even though metals are not biodegradable materials and do not promote bone tissue regeneration, they are widely used in implants for bone healing, and are worth mentioning. The main advantages of metallic implants are stiffness and 
high load-bearing mechanical properties combined with an absence of body immune response [23]. For these reasons, they are used frequently in bone surgery for tissue restoration. The mostly used metals are titanium and its alloys, and stainless steel; they seem to be useful, but require invasive procedures for implantation [24]. Classic metal implants do not promote osteoinduction or osteoconduction, and they do not improve bone regrowth. The metal implants are often withdrawn when bone healing is completed, implicating a second surgery associated with pain, high risk of infection, and further days of immobilization. Problems associated with stress shielding, fatigue, and loosening of implant are often noted with metal implants, leading to a second substitution surgery [25].

Biomaterials - namely biocompatible polymers, ceramic and bioglass - have the advantages that they integrate into the surrounding tissue without being rejected and minimize host reactions at the implant site [26]. This is an important property noted by many authors. Materials with these characteristics seem to accelerate tissue healing, and, moreover, an explant surgical procedure is not required when polymeric scaffolds are used, as the biomaterial is reabsorbed, or completely integrated with new tissue.

Scaffolds for bone regeneration can be made of diverse materials: polymers or polymers combined with calcium phosphate minerals as hydroxyapatite, or to other compounds, such as single-walled or multi-walled-carbon nanotubes [27]. They should meet all requirements of injectable products, such as sterility and apyrogenicity, because they are intended for implantation into the human body. Biocompatibility is an unavoidable requirement of the product: if it is a temporary scaffold, it should be biocompatible and bio-reabsorbable with controlled degradation and resorption rate. They can also provide a controlled release of specific bioactive factors in order to enhance or guide the regeneration events [28].

In the course of tissue regeneration, a biocompatible scaffold will allow cell adhesion and induce cell proliferation and differentiation without triggering inflammatory responses or immune rejection [29]. An ideal bone scaffold must have three fundamental features: it should be osteogenic, osteoconductive, and osteoinductive. An osteogenic material can generate bone tissue, which is a characteristic unique to osteoblasts [30]. Thus, the "living" bone can be considered only on the basis of a really osteogenic scaffold. Moreover, to ensure that the osteogenicity is retained in bone grafts, the transplant must be collected and used as quickly as possible to facilitate cell survival after surgical trauma [30, 31]. To fabricate a bone scaffold, an ideal biomaterial must also possess other properties, such as being bio-inert, biocompatible, bioactive, and biodegradable, possessing suitable mechanical properties. Furthermore, the biomaterial should also be able to withstand sterilization in order to avoid infections, and be interconnected and demonstrate controlled porosity [31]. In addition, it should be able to undergo efficient resorption in the course of bone regeneration. The scaffold-cell interaction must also ensure easy penetration, distribution, and proliferation of seeded cells [31]. The biomaterial should be $90 \%$ porous, with a suitable pore diameter to enable the cells to penetrate the biomaterial, thus ensuring regrowth of new bone tissue and its optimal vascularization. Finally, it is also essential that the scaffold biomaterial must be efficiently resorbed, with the deposition of new bone tissue, so that the new bone may replace it entirely, while maintaining the shape and thickness [32]. Craniofacial scaffolds (having several applications in dentistry) must fill three-dimensionally complex defects and provide adequate resistance to temporary load during regeneration [33].

Depending on their composition, polymer-based scaffolds can be classified as natural scaffolds, synthetic scaffolds, unblended scaffolds, and composite scaffolds [34]. The desired longevity of the polymeric scaffold implicates the use of bio-inert or biodegradable polymers, and their stability involves application of unblended or composite polymers, whereas the desired cellular interactions guide the choice of naturally- or synthetically-derived polymers [35]. The materials most commonly used for tissue regeneration include calcium phosphate ceramics like hydroxyapatite (HA) and beta-tricalcium phosphate ( $\beta$-TCP), synthetic polymers such as poly glycolic acid(PGA) and poly(lactic-co-glycolic) acid (PLGA), and naturally occurring biodegradable polymers such as collagen, hyaluronic acid, silk fibroin, gelatin, and chitosan [36].

Natural polymers have good biocompatibility, and they can be easily modified and processed into various structures [37]. However, their provenance from animal sources can increase the risk of pathogen transmission and immune rejection. Moreover, their poor mechanical strength does not assure whole protection of the seeded cells, slowing the healing process and in the worst-case leading to implantation failure [35]. An example is represented by collagen, which is used unblended for cartilage regeneration and, in association with other polymers or materials (composite scaffolds), for bone tissue regeneration. Collagen, hyaluronic acid (HA), carboxymethyl cellulose (CMC), and chitosan are some of the most studied natural polymers for bone regeneration [37].

The advantage of synthetic biodegradable polymer is their versatile behavior. Their properties such as mechanical strength and biodegradation rate depend on their molecular weight and composition, which can be tailored according to specific parameters. However, a lack of biological signalling and the resulting deficiency of cell response are frequent critical issues of this type of polymers [10].

Synthetic polymer degradation is mainly driven by hydrolysis, while natural polymers are degraded mostly through enzymatic pathways or combined with hydrolysis. The most-studied and used synthetic polymers are poly-alpha-hydroxy acids and derivatives, polycaprolactone (PCL) [38].

\section{Stem cells in the scaffolds}

The ability of a stem cell to differentiate into many different cell types offers great potential in regenerative medicine [39]. Dependent on their original source, these cells are classified as embryonic stem cells (ESCs) and adult stem cells, with the former extracted from embryos developed from in vitro 
fertilized eggs, and the latter derived from adult tissue and supported to maintain and repair the same tissue [40].

In general, the stem cells are divided into three main types that can be utilized for tissue repair and regeneration: 1) the embryonic stem cells derived from embryos (ES); 2) the adult stem cells that are derived from adult tissue; and 3) the induced pluripotent stem (iPS) cells that have been produced artificially via genetic manipulation of the somatic cells [41]. Human ESCs (hESCs), human BMMSCs (hBMMSCs), and human umbilical cord-derived mesenchymal stem cells (hUCMSCs) have mostly been studied for craniofacial tissue engineering. hESCs are harvested from human embryos 5-7 days old, and do not normally exist in the human body [42]. They fall under the pluripotent stemcell classification and have an ability to form three main germ layers: endoderm, mesoderm and ectoderm [43]. They possess the highest pluripotency level, and are able to proliferate quite rapidly. hBMMSCs and hUCMSCs are harvested from bone marrow and the umbilical cord, respectively, and have been extensively studied in the tissue-engineering field [43]. Both cell lines are multipotent and can be differentiated into osteoblasts, chondrocytes, myoblasts, adipocytes, fibroblasts and nerve tissues. hBMMSCs are considered to be the current gold standard cell lines [44]. However, they have certain drawbacks such as an invasive procedure to harvest the cells, a limited number of cells, and lower self-renewal and proliferation capacity due to patient aging and diseases such as arthritis. To avoid these drawbacks, hUCMSCs can be a good replacement [45].

Popular stem cell used in dental tissue engineering is the periodontal ligament stem cells (PDLSC) which is extracted from discarded teeth and has the potential to generate the cementum and periodontal ligament-like structure. Studies have shown that these stem cells also have the potential to develop into the osteogenic and adipogenic tissues in vitro, opening up multiple opportunities for tissue engineering from dental-derived stem cells [46].

\section{Scaffolds and drug delivery}

Polymer matrix, or scaffold, represents a $3 \mathrm{D}$ platform that may serve the dual purpose of cell support and cells/growth factors (GFs)/drugs delivery [10]. Porosity is perhaps the most important structural scaffold requirement, including macropores ( $>50 \mathrm{~nm},<300 \mathrm{~nm}$ ) plausible for cell penetration and tissue in-growth, and smaller pores such as micropores $(<2 \mathrm{~nm})$ and mesopores $(>2 \mathrm{~nm},<50 \mathrm{~nm})$ which allow nutrient transport and waste of metabolic products, permitting cell growth. Whenever scaffolds are made of biodegradable polymers, scaffold biodegradation also contributes to the release of a loaded drug. Scaffold degradation rate is a very important parameter to be set, in order to achieve suitable control of drug release. Moreover, scaffold biodegradation should be synchronized with the rate of tissue growth [10].

Enhanced functionality of these already complex matrices has been achieved by incorporating drugs or drugs encapsulated into drug delivery systems [47]. The drug-releasing scaffolds permit local delivery of an adequate dose of bioactive molecules for a desired period, minimizing active agent release to non-targeted sites, supporting and promoting tissue regeneration, which normally occurs over a long time span [48]. From this viewpoint, TE can be viewed as a special case of controlled drug delivery combined with scaffolding materials. Drug-releasing scaffolds are new multifunctional platforms able to achieve drug delivery to specific sites with high loading rates and efficiency, and control the tissue regeneration process [48].

Cells can be seeded onto the 3D polymer scaffolds or 3D-porous matrix, in order to achieve an engineered tissue. Moreover, cell delivery can also be achieved through their microencapsulation, as commonly performed with alginate microcapsules [49].

Depending on the incorporation method used and the biomaterial characteristics (as discussed above), drug release rate may be controlled by various processes, such as diffusion, polymer erosion or degradation, and swelling of polymer followed by diffusion [10,47]. Drugs release profile can be altered by modifying polymer properties or adjusting physical and chemical properties of the scaffold such as porosity, pore size, and shape, polymer crosslinking degree, and degradation rate [48]. Additionally, drugs and cells can be encapsulated into biodegradable particulate systems having the potential to be retained in specific tissues, providing their sustained release [50].

Biomaterials for drug delivery can be designed in various morphologies (e.g., micelles, vesicles, particles, tubes, scaffolds, or gels) and architecture (reservoirs or matrices) [51]. Drugs can be safely encapsulated in non-cytotoxic and biodegradable synthetic polymers such as polylactic acid (PLA), polyglycolic acid (PGA), their copolymer polylactic-co-glycolic acid (PLGA), poly- $\varepsilon$-caprolactone (PCL), polyethylene, polymethylmethacrylate (PMMA), or natural hydrogels such as alginate, gelatin, fibrin, collagen, and chitosan [52,53].

Worth of note, many biomaterials used for drug delivery systems are the same as for scaffold manufacturing, creating a perfect interaction between the areas of drug delivery and tissue regeneration research [52].

\section{Conclusion}

This review article aims to discuss recent advances in craniofacial tissue engineering using polymeric scaffolds. Craniofacial tissue is the region that should meet highest demands in tissue engineering, due to associated aesthetic and functional characteristics required. For the successful regeneration of complex tissue structures and restoration of aesthetic characteristics, numerous biomaterials and scaffolds have been used. Before deciding on biomaterials and scaffolds, we need a good understanding of the complex anatomical structures of craniofacial tissue. We discussed various scaffolds and their possible components used in recent studies.

The studies are addressed to finding biomaterials with properties suitable to support tissue regeneration, and to obtain drug delivery systems which are able to modulate drug release. Such scaffold/drug delivery systems combine several advantages such as: 
1) local drug delivery with improved bioavailability and reduced adverse effects with respect to systemic drug administration;

2) sustained drug release;

3) ability of combining two or more drugs in a single scaffold.

In the future an experimental study of the scaffolds as drug and stem cell carriers is planned with evaluation of local antibacterial action and tissue regeneration.

No conflicts of interest are reported.

\section{References}

1. Zhao H, Chai Y. Stem cells in teeth and craniofacial bones. J Dental Res. 2015; 94 (11):1495-1501.

2. Rai R, Raval R., Khandeparker RVS, Chidrawar SK, Khan AA, Ganpat MS. Tissue engineering: step ahead in maxillofacial reconstruction. J Int Oral Health 2015; 7:9:138-142.

3. Malhotra N, Kundabala M, Acharya S. Current strategies and applications of tissue engineering in dentistry - A review part 1. Dent Update 2009; 36: 577-582.

4. Tobita M, Mizuno H. Adipose-derived stem cells and periodontal tissue engineering. Int J Oral Maxillofac Implants. 2011; 1:487-493.

5. Juodzbalys G, Kubilius M. Clinical and radiological classification of the jawbone anatomy in endosseous dental implant treatment. J Oral Maxillofac Res. 2013; 4(2):e2. doi: 10.5037/jomr.2013.4202.

6. Sheikh Z, Hamdan N, Ikeda Y, Grynpas M, Ganss B, Glogauer M. Natural graft tissues and synthetic biomaterials for periodontal and alveolar bone reconstructive applications: A review. Biomater Res. 2017; 21:9.

7. Kaigler D, Mooney D. Tissue engineering's impact on dentistry. J Dent Educ. 2001; 65:456-462.

8. Kumas V, Abbas AK, Fousto N, Aster J. Tissue renewal, regeneration, and repair. In Robbins and Cotran Pathologic Basis of Disease, 9th ed. Elsevier: Amsterdam, The Netherlands 2014; Chapter 3.

9. Samorezov JE, Alsberg E. Spatial regulation of controlled bioactive factor delivery for bone tissue engineering. Adv Drug Deliv Rev. 2015; 84:45-67.

10. Dorati R, DeTrizio A, Modena T, Conti B, Benazzo F, Gastaldi G, Genta I. Biodegradable scaffolds for bone regeneration combined with drug-delivery systems in osteomyelitis therapy. Pharmaceuticals. 2017; 10(4). pii: E96. doi: 10.3390/ph10040096.

11. Rasperini G, Pilipchuk SP, Flanagan CL, Park CH, Pagni G, Hollister SJ, Giannobile WV. 3D-printed bioresorbable scaffold for periodontal repair. J Dent Res 2015; 94:153S-157S.

12. Yao Q, Wei B, Guo Y, Jin C, Du X, Yan C, Yan J, Hu W, Xu Y, Zhou Z, et al. Design, construction and mechanical testing of digital 3D anatomical data-based PCL-HA bone tissue engineering scaffold. J Mater Sci Mater Med. 2015; 26:5360.
13. Park SH, Park DS, Shin JW, Kang YG, Kim HK, Yoon TR, Shin JW. Scaffolds for bone tissue engineering fabricated from two different materials by the rapid prototyping technique: PCL versus PLGA. J Mater Sci Mater Med. 2012; 23:2671-2678.

14. Williams JM, Adewunmi A, Schek RM, Flanagan CL, Krebsbach PH, Feinberg SE, Hollister SJ, Das S. Bone tissue engineering using polycaprolactone scaffolds fabricated via selective laser sintering. Biomaterials. 2005; 26:4817-4827.

15. Long DW, Johnson NR, Jeffries EM, Hara H, Wang Y. Controlled delivery of platelet-derived proteins enhances porcine wound healing. J Control Release. 2017; 253:73-81.

16. Pacheco H, Vedantham K, Young AA, Marrito I, El-Gannam $A$. Tissue engineering scaffold for sequential release of vancomycin and rhBMP2 to treat bone infections. J Biomed Mater Res A. 2014; 102:4213-4223.

17. Kretlow JD, Klouda L, Mikos AG. Injectable matrices and scaffolds for drug delivery in tissue engineering. Adv Drug Deliv Rev. 2007; 59:263-273.

18. Levengood SL, Zhang M. Chitosan-based scaffolds for bone tissue engineering. J Mater Chem B. Mater Biol Med. $2014 ; 2: 3161-3184$.

19. Mckee MD. Extracellular matrix and mineralization of craniofacial bone. In: Mineralized Tissues in Oral and Craniofacial Science: Biological Principles; John Wiley \& Sons : Hoboken, NY, USA, 2012.

20. Dreifke MB, Ebraheim NA, Jayasuriya AC. Investigation of potential injectable polymeric biomaterials for bone regeneration. J Biomed Mater Res A. 2013; 101:2436-2447.

21. Schwartz AM, Schenker ML, Ahn J, Willett NJ. Building better bone: the weaving of biologic and engineering strategies for managing bone loss. J Orthop Res. 2017; 35:18551864.

22. Ye F, Zeng Z, Wang J, Liu H, Wang H, Zheng Z. Comparison of the use of rhBMP-7 versus iliac crest autograft in single-level lumbar fusion: A meta-analysis of randomized controlled trials. J Bone Miner Metab. 2018; 36(1):119-127. doi: 10.1007/s00774-017-0821-z.

23. Li H, Ji Q, Chen X, Sun Y, Xu Q, Deng P, Hu F, Yang J. Accelerated bony defect healing based on chitosan thermosensitive hydrogel scaffolds embedded with chitosan nanoparticles for the delivery of BMP2 plasmid DNA. J Biomed Mater Res (Pt A). 2017; 105A:265-273.

24. Asti A, Gastaldi G, Dorati R, Saino E, Conti B, Visai L, Benazzo F. Stem cells grown in osteogenic medium on PLGA, PLGA/HA, and titanium scaffold for surgical applications. Bioinorg Chem Appl. 2010:831031. doi: 10.1155/2010/831031.

25. Benazzo F, Botta L, Scaffino MF, Caliogna L, Marullo M, Fusi S, Gastaldi G. Trabecular titanium can induce in vitro osteogenic differentiation of adipose derived stem cells without osteogenic factors. J Biomed Mater Res A. 2014; 102:2061-2071. 
26. Williams DF. On the mechanisms of biocompatibility. Biomaterials. 2008; 29:2941-2953.

27. Dreifke MB, Ebraheim NA, Jayasuriya AC. Investigation of potential injectable polymeric biomaterials for bone regeneration. J Biomed Mater Res A. 2013; 101: 2436-2447.

28. Ishack S, Mediero A, Wilder T, Ricci JL, Cronstein BN. Bone regeneration in critical bone defects using three-dimensionally printed $\beta$-tricalcium phosphate/hydroxyapatite scaffolds is enhanced by coating scaffolds with either dipyridamole or BMP-2. J Biomed Mater Res. 2017; 105: 366-375.

29. Evans ND, Gentleman E, Polak JM. Scaffolds for stem cells . Materials Today. 2006; 9:12:26-33.

30. Ceccarelli G, Presta R, Benedetti L, Cusella De Angelis MG, Lupi SM, Rodriguez y Baena R. Emerging perspectives in scaffold for tissue engineering in oral surgery. Stem Cells International. 2017:4585401. doi: 10.1155/2017/4585401.

31. Polo-Corrales L, Latorre-Esteves M, Ramirez-Vick JE. Scaffold design for bone regeneration. J Nanosci Nanotechnol. 2014; 14(1):15-56.

32. Abukawa H, Papadaki M, Abulikemu M et al. The engineering of craniofacial tissues in the laboratory: a review of biomaterials for scaffolds and implant coatings. Dental Clin North Amer. 2006;50(2):205-216.

33. Fillingham Y, Jacobs J. Bone grafts and their substitutes. Bone Joint Journal. 2016; 98-B(1 Suppl A):6-9. doi: 10.1302/0301-620X.98B.36350

34. Dorati R, Colonna C, Genta I, Conti B. Polymer scaffolds for bone tissue regeneration in active implants and scaffolds for tissue regeneration. Tissue Engineering and Biomaterials Book Series; Springer: Berlin, Germany, 2011; 8: 259-285.

35. Wu J, Xie L, Zhi W, Lin Y, Chen Q. Biomimetic nanofibrous scaffolds for neural tissue engineering and drug development. Drug Discov Today. 2017; 22:1375-1384.

36. Lanza R, Langer R, Vacanti JP, eds. Principles of tissue engineering. Elsevier, 2013.

37. Wu J, Chen Q, Liu W, He Z, Lin JM. Recent advances in microfluidic 3D cellular scaffolds for drug assays. Trends Anal Chem. 2017; 87:19-31.

38. Dorati R, Colonna C, Genta I, Modena T, Conti B. Effect of porogen on the physico-chemical properties and degradation performance of PLGA scaffolds. Polym Degrad Stab. 2010; 95: 694-701.

39. Chen KG, Johnson KR, McKay, R.; Robey, P.G. Concise review: Conceptualizing paralogous stem-cell niches and unfolding bone marrow progenitor cell identities. Stem Cells. 2018; 36(1):11-21.

40. Hu L, Liu Y, Wang S. Stem cell-based tooth and periodontal regeneration. Oral Dis. 2017; 1-10.

41. Martin GR. Isolation of a pluripotent cell line from early mouse embryos cultured in medium conditioned by teratocarcinoma stem cells. Proc Nat Acad Sci USA. 1981; 78: 7634-7638.
42. Zhang J, Chen J. Bone Tissue Regeneration-Application of Mesenchymal Stem Cells and Cellular and Molecular Mechanisms. Curr Stem Cell Res Ther. 2017; 12: 357-364.

43. Liu X, Wang P, Chen W, Weir MD, Bao C, Xu HH. Human embryonic stem cells and macroporous calcium phosphate construct for bone regeneration in cranial defects in rats. Acta Biomater. 2014; 10: 4484-4493.

44. Szpalski C, Barbaro M, Sagebin F, Warren SM. Bone tissue engineering: Current strategies and techniques-Part II: Cell types. Tissue Eng. Part B Rev. 2012; 18: 258-269.

45. Chen W, Liu J, Manuchehrabadi N, Weir MD, Zhu Z, Xu $\mathrm{HH}$. Umbilical cord and bone marrow mesenchymal stem cell seeding on macroporous calcium phosphate for bone regeneration in rat cranial defects. Biomaterials 2013; 34 : 9917-9925.

46. Gaihre B, Uswatta S, Jayasuriya AC. Reconstruction of craniomaxillofacial bone defects using tissue-engineering strategies with injectable and non-injectable scaffolds. J Funct Biomaterials. 2017; 8(4). pii: E49. doi: 10.3390/ jfb8040049

47. Galvez-Martín PM, Martin JM, Ruiz A, Clares B. Encapsulation in cell therapy: methodologies, materials, and clinical applications. Curr Pharm Biotechnol. 2017; 18: 365-377.

48. Krishnan R, Alexander M, Robles L, Foster CE 3rd, Lakey JR. Islet and stem cell encapsulation for clinical transplantation. Rev Diabet Stud. 2014; 11: 84-101.

49. Klausner EA, Zhang Z, Wong SP, Chapman RL, Volin MV, Harbottle RP. Corneal gene delivery: chitosan oligomer as a carrier of $\mathrm{CpG}$ rich, $\mathrm{CpG}$ free or S/MAR plasmid DNA. J Gene Med. 2012; 14: 100-108.

50. Thatiparti TR, Shoffstal AJ, Von Recum HA. Cyclodextrin-based device coatings for affinity-based release of antibiotic. Biomaterials. 2010; 31: 2335-2347.

51. Isa T, Zakaria ZA, Rukayadi Y, Mohd Hezmee MN, Jaji AZ, Imam MU, Hammadi I, Mahmood K. Antibacterial activity of ciprofloxacine-encapsulated cockle shells calcium carbonate (aragonite) nanoparticles and its biocompatability in macrophages J774A.1. Int J Mol Sci. 2016 May 19;17(5). pii: E713. doi: 10.3390/ijms17050713

52. Wang L, Hu C, Shao L. The antimicrobial activity of nanoparticles: Present situation and prospects for the future. Int J Nanomed. 2017; 12: 1227-1249.

53. Posadowoska U. Gentamicin-loaded PLGA nanoparticles as local drug delivery system for the osteomyelitis treatment. Acta Bioeng Biomech. 2015; 17: 41-48. 


\title{
Перспективы применения искусственных структур (скаффолдов) в стоматологии и краниофациальной хирургии: обзор литературы
}

\author{
Андрей И. Яременко ${ }^{1}$, Анна В. Лысенко ${ }^{1}$, Елизавета А. Иванова ${ }^{1}$, Александр Д. Вилесов ${ }^{1,2}$, Олег В. Галибин ${ }^{1}$, \\ Николай Л. Петров ${ }^{1}$, Павел А. Кириллов ${ }^{1}$
}

${ }^{1}$ Кафедра челюстно-лицевой хирургии и НИИ детской онкологии, гематологии и трансплантологии им. Р. М.Горбачевой, Первый Санкт-Петербургский государственный медицинский университет им. И. Павлова, Санкт-Петербург, Россия ${ }^{2}$ Институт высокомолекулярных соединений Российской Академии наук, Санкт-Петербург, Россия

\section{Резюме}

Регенеративная медицина является развивающейся областью биотехнологий, сочетающая различные аспекты медицины, в том числе клеточную и молекулярную биологию, материаловедение и биологическую инженерию для регенерации или замены тканей. Регенерация кости - перспективный подход в стоматологии, и она рассматривается как идеальная клиническая стратегия в лечении болезней, повреждений и дефектов максиллофациальной области. Успехи тканевой инженерии привели к разработке инновативных опорных структур, что дополняется прогрессом в клеточной терапии. Регенерация кости in vitro может достигаться сочетанием стволовых клеток, опорных структур и биоактивных факторов. Возможное улучшение процесса восстановления поврежденных тканей может быть достигнуто путем нагрузки скаффолдов лекарственными веществами, а также генетическим материалом, факторами роста или другими белками, способствующими восстановлению ткани. Данный обзор сосредоточен на различных биоматериалах, применяемых в стоматологии, в качестве потенциальных скаффолдов (субстратов) для регенерации кости при лечении костных дефектов или хирургических вмешательствах. В частности, рассматриваются характеристики и типы таких структур, а также обсуждается литература о локальной доставке антибиотиков при комбинированном применении скаффолдов и систем доставки лекарственных препаратов.

\section{Ключевые слова}

Краниофациальная хирургия, скаффолд, тканевая инженерия, стволовые клетки, доставка препаратов. 